\title{
Reducing Students' Pronunciation Anxiety by Utilizing WhatsApp Group in Learning English Consonant Sounds
}

\author{
Vivi Aulia \\ viviauliavasa@yahoo.com \\ STKIP PGRI Banjarmasin, Indonesia
}

\begin{abstract}
This research aims at describing the utilization of WhatsApp group to reduce students' pronunciation anxiety in learning English consonant sounds. It is conducted to the first semester of English Department students at STKIP PGRI Banjarmasin batch 2018 in Pronunciation Practice course. The instruments of this research are the documentation of students' scores on voice records sent to WhatsApp group and the questionnaire. Both the instruments are analyzed quantitatively. The documentation of students' voice records is analyzed to see their progress of practicing English consonant sounds during eight meetings. Meanwhile, the questionnaire is analyzed to get their impressions and personal feelings whether the use of WhatsApp group help them to reduce their anxiety as well as fear of making error in pronunciation practice. The result of students' voice record documentation shows that there are $56 \%$ students who have good scores, $42 \%$ students have enough scores, and $5 \%$ of students have fair scores. It indicates that the result of students' pronunciation practice needs to be improved. The students should carry out regular practice to get maximal pronunciation ability. The result of questionnaire shows that there are $78 \%$ of them state that WhatsApp group helps them much in learning, feel enjoy, have selfconfidence as the result of having more relax after involving on class discussion using WhatsApp group.
\end{abstract}

Keywords: Pronunciation anxiety, WhatsApp group, learning, and English consonant sounds

\section{INTRODUCTION}

Having ability to communicate orally and written using English as a foreign language is one of basic motivation mostly that must be had by Indonesian students in learning English. Mastering English as one of international language around the world is also the requirement for those who want to engage in world interaction and today's job market. As a consequence of learning English, students are not only encouraged to master four English language skills as basis ways to do communication and interaction among people, but also have to develop their abilities to master English language components, like structure, vocabulary, and pronunciation. Four English language skills cannot be meaningful and will be meaningless without the ability to allocate much attention to learn its language components. Structure, vocabulary, and pronunciation play vital role in supporting the success of using language skills in English communication. 
Among three of English language components that should be mastered by students to support the use of language skills, pronunciation is considered to be the difficult and complicated one for students. The difficulty of pronunciation to be learned by students does not mean that the other two parts are easier to learn. Grammar and vocabulary are complicated to learn in particular case since they need strong energy to activate the memory and the brain memorizing the English words as well as the English grammar. Otherwise, pronunciation aspect is more difficult since it relates with the use of our speech organ producing proper English speech. Later, this will determine the success of oral interaction and communication among people. The communicative competence is determined from the English words he/she produces understandably for the listener. Indeed, the pronunciation aspect is commonly neglected in the field of English language teaching due to the complexity of its features.

Since pronunciation aspect impacts on learners' communicative competence and performance, the lack of pronunciation skills will reduce the students' self-confidence and limit their social interaction (Gilakjani and Sabouri, 2016:967). This is because pronunciation learning covers individual practice on speech that determines whether the words pronounced is understandable in communication or not. Many students consider that it is a hard work to produce the intelligible pronunciation. English pronunciation which involve both phonemes and suprasegmental features cause anxiety and feeling nervous of making error for many learners. There is a feeling of worry making error in pronouncing English words that will be laughed by their classmates. As a result, many students are not confident to perform their individual practice in front of their friends. In particular, general observation suggests that those who start to learn English after their school years most likely have serious difficulties in acquiring proper pronunciation (Gilakjani and Ahmadi, 2011:74).

The pronunciation of English consists of two main features. They are phonemes containing of vowels and consonants, and suprasegmental feature containing of stress and intonation (Kelly,2000:1). At the beginning of learning pronunciation, phonemes are the basic elements the students have to pronounce fluently since this involves unit of sounds and how each of English sound is produced. The distribution of English phonemes are considered difficult since there are 20 vowel sounds (including 12 diphtongs) and 24 consonants sounds should be practiced by students seriously and intensively. Of those 24 consonants, there are some sounds that do not exist in other languages. As a result, it can be extremely difficult for students to understand and learn how to articulate such sounds. As a consequence, the production and articulation of students learning these sounds are inaccurate. For a long term of learning process, these reduce students' confidence to sustainable learning, feeling anxious of making error, and having low motivation to master English sounds as a basic to have speaking ability.

STKIP PGRI Banjarmasin as one of the universities in Banjarmasin has English Department that trains and gives aid to students in mastering English that will eventually prepare them to be professional English teachers. Within two semesters, the students are trained on how to improve their abilities on English pronunciation practice. They are Pronunciation Practice course given in the first semester and Pronunciation in ELT course 
given in the second semester. Pronunciation Practice focuses on learning and practicing the features of English pronunciation intensively while Pronunciation in ELT focuses on learning the concept of English pronunciation as well as giving the knowledge of teaching and learning English pronunciation (STKIP PGRI Banjarmasin, 2017).

The English Department students of STKIP PGRI Banjarmasin who take Pronunciation Practice course consider that they have many difficulties in learning English pronunciation. The major problem they faced is the difference of English sound system with their mother tongue and with Indonesian language, particularly for consonant sounds. Some of them do not have problem in learning English consonants due to their experiences that they have learned about it before entering the university. They become the most active learners and become dominant in the class. On the other hand, there are many students in the classroom who learn English for the first time when they take English major at the university. They seem to have feeling shy to perform their voices in the classroom. Moreover, they become minor and passive learners in the Pronunciation Practice course since they always make errors when learning such consonant sounds. Their self-confidences are very low to perform their voices and become introvert in the activities that should be learned the English sounds together in the class.

Efforts to enhance students' confidence in learning English pronunciation as well as reduce the students' anxiety, particularly in learning pronunciation of consonant sounds, are needed to facilitate students building their self-confidence. As we live in $21^{\text {st }}$ century, the development of technology offers many kinds of media that enable students learn everything easier. One of them is social media that can be utilized positively to help students in learning English pronunciation. Social media which are almost used by people provide mobile and accessible application that support learning. Facebook, Google Drive, Youtube, Path, Line, Instagram, Telegram, and WhatsApp are kinds of online and offline social media tools already familiar used by people around the world. By utilizing these application programs, the students get possible benefits to facilitate them in learning.

Ahad and Lim (2014:189) define WhatsApp as the free communication application introduced in 2009 and has 500 million users in the world. WhatsApp as the new mobile application offers the service for us sending the messages. It proposes the real-time text that functions to share the information or media content such like audio, video files, images, and data location easily and quickly. Among many kinds of social media tools, WhatsApp becomes the new application the learners use utilize its features to communicate each other with their friends. By teacher's role in creating WhatsApp group consisting of classroom members, all students and teacher can share and activate the information each other about learning material and conducting classroom discussion. Dealing with English pronunciation learning, WhatsApp as a communication program for student groups and teachers is used to record the students' practices of pronouncing the sounds. Students can access WhatsApp easily using their smartphones as well as their laptops. Applying audio recorder available on students' smartphones or laptops, the students are able to record their voices and display the voices each other in the group, hear their other classmates' voices, hear the model of pronunciation record performed by native speaker, and give feedback each other for those who still produce the inaccurate sounds. By sharing their voices to 
each other, they are expected to feel confident without having any anxiety of making error in pronouncing the English sounds.

Reducing students' pronunciation anxiety as well as raising the students' self-confidence are important in order to produce successful learning. If they have high self-confidence, they will be happy to learn everything, feel comfortable to learn everything, and do not quit when difficulties come to them. On the other hand, the students who are of lack of selfconfidence will most probably have a negative attitude towards the course and the classroom interaction. They are unhappy, feel uncomfortable joining the course, fear of failure, have high anxiety towards the teacher and course during the class, and refrain from interacting and participating in classroom activities (Tuncel,2015:2576).

This research focuses on the investigation of utilizing WhatsApp social media application to facilitate students recording their voices in learning pronunciation of English consonant sounds. They use audio recorder to record their voices and display it to the WhatsApp group. Then, they should discuss each other, give feedback to their friends' voice records, and if any, correct the inaccurate voice record by giving model of how to pronounce the proper sounds. Some previous researchers have conducted similar research on utilizing WhatsApp as a social media application in learning. Firstly, Ta'amneh (2017:143-151) conducted a research about the use of WhatsApp messenger in learning English. The result of the research shows that the students who use WhatsApp application in learning English language perform better than those who use traditional way. This research also concludes that English lessons can be learned more effectively through integrating technological applications such as WhatsApp messenger in learning English than the traditional methods.

Next, Hamad (2017:74-87) conducted a research about the use of WhatsApp to enhance students' learning of English language. The result of his research shows that using WhatsApp application enhances students' learning and enthusiasm, helps students to develop English skills, enriches their vocabularies, and learns from their mates' mistakes. This research also concludes that there are some advantages of utilizing WhatsApp in learning of English. WhatsApp application helps students overcome their fear of using the language, enabling students to learn from their colleagues' mistakes, helping the students to believe in their abilities and to have confidence, and increasing students' motivation towards learning.

Based on the research finding that WhatsApp application is useful as one of alternative of learning aid, the researcher is interested to examine and investigate the use of it in pronunciation activity. Since there are many students who take Pronunciation Practice course have problems on the learning attitude, the use of WhatsApp application is used mainly to help them reduce their pronunciation anxiety, to build their self-confidences, and to stimulate them to be active learners. Therefore, a descriptive study on the use of this tool is conducted on the first semester students batch 2018 taking Pronunciation Practice course at the English Department of STKIP PGRI Banjarmasin. The objective of this research is to describe the utilization of WhatsApp groups in learning English consonant sounds and see whether the use of it will enhance the students' confidence and reduce their anxiety in pronunciation learning. 
ELT Worldwide Vol 5 No 2 (2018)

Aulia : Reducing Students' Pronunciation Anxieti by ...

\section{METHOD}

This research is conducted in Pronunciation Practice course of English majors in STKIP PGRI Banjarmasin. The approach used is quantitative in which it presents the data using number. This research uses descriptive method aiming at describes the utilization of WhatsApp group to enhance students' confidence in learning English pronunciation sounds. The selection of English consonant sounds as the learning material to be investigated is based on the consideration that there are different characteristics between English and Indonesian consonants sounds. For instance, the number of English consonant is 24 sounds while the number of Indonesian consonants is 23 sounds. Besides that, there are some English sounds that do not occur in Indonesian. For instance, there is no sound /ny/ in English sound. These differences are considered as the cause of difficulties for students to pronounce that finally will reduce their self-confidence.

There is one class of English major students batch 2018 involved in this research. The total number of them is 18 students. Moreover, the instruments used for collecting the data are documentation of students' scores on voices record sent to WhatsApp group and questionnaire. First of all, documentation of students' voices record is used to know the students' learning progress and result after doing pronunciation practice with their pairs. In this case, the teacher instructed them to work with their pairs practicing the pronunciation of English consonant sounds. After that, they recorded their voices that pronounce the sound being practiced in each meeting and send it to the WhatsApp group has been created by the teacher. There are eight meetings totally for students work in pair learning all English consonant sounds, recording their voices, sending their voices to WhatsApp group, and conducting interactive discussion toward these voice records. The distribution of English consonant sounds that should be practiced in each meeting is presented in Table 1 as follows:

Table 1 The Distribution of English Consonant Sounds to be Learned and Recorded

\begin{tabular}{|c|c|}
\hline Meeting & $\begin{array}{c}\text { The Consonant Sounds Should be Learned and Recorded by } \\
\text { Students }\end{array}$ \\
\hline 1 & the plosives /p/, /b/, /t/, and /d/ \\
\hline 2 & the plosives $/ \mathrm{k} /, / \mathrm{g} /$, the affricates $/ \mathrm{t} / /, / \mathrm{d}_{3} /$ \\
\hline 3 & the fricatives $/ \mathrm{f} /, / \mathrm{v} /, / \Theta /$, and $/ ð /$ \\
\hline 4 & the fricatives $/ \mathrm{s} /, / \mathrm{z} /, / \mathrm{J} /$, and $/ \mathrm{z} /$ \\
\hline 5 & the fricative $/ \mathrm{h} /$ and the nasal $/ \mathrm{m} /$ \\
\hline 6 & the nasals $/ \mathrm{n} /$ and $/ \mathrm{n} /$ \\
\hline 7 & the lateral /l/ and the approximant $/ \mathrm{r} /$ \\
\hline 8 & the approximants $/ \mathrm{w} /$ and $/ \mathrm{j} /$ \\
\hline
\end{tabular}

In details, the instructional activity in Pronunciation Practice course to utilize WhatsApp group is described as follows:

In the early of the meeting, asking the students to make a copy of the Pronunciation Practice module has been provided by the lecturer; 
$>$ Giving explanation on the concept of English consonant sounds, showing video tutorial of native speaker in pronouncing the English consonants, and describing the practice activities will be carried out by students using WhatsApp group;

Asking students to move their seats and work in group of two;

$>$ Asking the students to practice each consonant sounds based on provided exercises on the module with their pairs. The material delivered is pronouncing example of words consisting of consonant sounds being learned, minimal pairs, dialogue, tongue twister, and spelling phonetic transcription;

> Monitoring each group to make sure that all the students follow the lecturer's instruction and observe the process of students' pronunciation learning in each group;

> Asking each student to record their voices on pronouncing the consonant sounds using audio recorder available on their smartphones;

Asking each student to send their voice records to WhatsApp group have been created by the lecturer;

$>$ If all the students have sent their voice records on WhatsApp group, giving them takehome assignment. They are asked to play all their classmates' voice records sent on WhatsApp group. They shoud hear, learn, and observe the others voices seriously and carefully. Then, they have to learn each other, give comment, give feedback on the others voices, and discuss everything about the consonant sounds from the voice records of all members of WhatsApp group. All the members have to participate actively on discussion. During this process, the lecturer monitored the on-going discussion and provided comment if it is necessary;

$>$ In the next meeting, delivering feedback towards the result of discussion on WhatsApp group related to the voice records have been sent by the students;

> Asking students to practice the sound, re-record their voices, and sent again to WhatsApp group to show the result of their practice process after getting feedback from others;

$>$ Administering additional meeting to hold sharing of learning experiences in utilizing WhatsApp group in learning pronunciation.

Next, the second instrument for collecting the data is questionnaire. It consists of some statements related to the opinion, point of view, and personal feeling of students whether the utilization of WhatsApp group reduces their pronunciation anxiety in learning English consonant sounds. The questionnaire is distributed at the end of meeting after the students accomplished their voices recordings for all consonant sounds. In this case, the students are asked to give comment on the use of WhatsApp group for learning, their impression of using WhatsApp group for learning, the usefulness of using WhatsApp group for learning, and the statement whether the use of WhatsApp group for learning affects to their selfconfidences.

Then, the researcher analyzes the data obtained from the instruments quantitatively. The documentation of students' voice records for 24 English consonant practiced are assessed by the lecturer using the Pronunciation assessment rubric presented in Table 2 as follows: 
ELT Worldwide Vol 5 No 2 (2018)

Aulia : Reducing Students' Pronunciation Anxieti by ...

Table 2 The Pronunciation Practice Assessment Rubric

\begin{tabular}{|c|c|c|}
\hline Grade & Score & Criteria \\
\hline Excellent & 80 & $\begin{array}{ll}- & \text { Almost error-free } \\
\text { - } & \text { Phonetically correct } \\
\text { - } & \text { Awareness of accent } \\
\text { - } & \text { Genuine effort to sound like native speaker }\end{array}$ \\
\hline Good & $70-79$ & $\begin{array}{l}\text { - Comprehensible, generally correct } \\
\text { - Occasional error }\end{array}$ \\
\hline Enough & $60-69$ & $\begin{array}{l}\text { Frequent errors that confuse listener and require } \\
\text { guessing at meaning }\end{array}$ \\
\hline Fair & $50-59$ & Many errors that interfere with comprehensibility \\
\hline Poor & $<50$ & $\begin{array}{l}\text { Most words and utterances contain errors, } \\
\text { incomprehensible, and little communication }\end{array}$ \\
\hline
\end{tabular}

The researcher assessed students' voices record using the rubric above for each meeting. During eight meetings, the students' voice records in pronunciation learning are assessed and evaluated whether there is improvement on their learning progress or not. The result of this analysis is calculated to get the average score for each student to meet the grade on Table 2. Meanwhile, the researcher analyzes the questionnaire which represents the students' personal feeling about the use of WhatsApp group to reduce their anxiety and to enhance their self-confidences. The students' responses are tabulated in form of table to find out the percentage response given based on the statement provided in the questionnaire. Those who have high percentage in each item of questionnaire present the dominant response given by them. Then, these results are discussed based on review of related literature.

\section{FINDINGS AND DISCUSSION}

This part presents the result of data that have been collected and the discussion of the findings based on literature in the relevant field.

\section{FINDINGS}

Findings of this research cover two areas. They are the result of documentation of students' voice records which are sent to WhatsApp groups in each meeting and the result of questionnaire distributed to students after they accomplish all the pronunciation learning activities. 
Aulia : Reducing Students' Pronunciation Anxiety by ...

\section{The Result of Documentation of Students' Voices Record}

As mentioned in the previous section that each student should learn and practice English consonant sound during eight meetings. At the end of each meeting, they have to record their sounds in pronouncing the sound and to send the record result to WhatsApp group. The scores of each student' voice records in each meeting is calculated to get the average score. This average score becomes their final scores in learning English consonant sounds. The final scores of students' voices are presented in Table 3 as follows.

Table 3 The Final Scores of Students' Voices Record

\begin{tabular}{cccccc}
\hline \multirow{2}{*}{ Meeting } & \multicolumn{5}{c}{ The Percentage of Students' Scores } \\
\cline { 2 - 6 } & Excellent & Good & Enough & Fair & Poor \\
\hline I & - & $48 \%$ & $47 \%$ & $5 \%$ & - \\
\hline II & - & $50 \%$ & $45 \%$ & $5 \%$ & - \\
\hline III & - & $55 \%$ & $40 \%$ & $5 \%$ & - \\
\hline IV & - & $55 \%$ & $45 \%$ & - & - \\
\hline V & - & $60 \%$ & $40 \%$ & - & - \\
\hline VI & - & $62 \%$ & $38 \%$ & - & - \\
\hline VII & - & $62 \%$ & $38 \%$ & - & - \\
\hline VIII & - & $60 \%$ & $40 \%$ & - & - \\
\hline Average & - & $\mathbf{5 6 \%}$ & $\mathbf{4 1 \%}$ & $\mathbf{5 \%}$ & - \\
\hline $\begin{array}{c}\text { Total number } \\
\text { of students }\end{array}$ & - & $\mathbf{1 0}$ & $\mathbf{7}$ & $\mathbf{1}$ & \\
\hline
\end{tabular}

Based on table 3 above, it can be concluded that there are $56 \%$ of students who have good score on recording their voices of pronouncing consonant sounds. It indicates that most of students show their progress on learning of pronouncing English consonant sounds. On the other hand, there are $41 \%$ of them who have enough score indicating that they need to improve their English consonant practice. This group of students still has problems on the way to pronounce some consonant sounds. Finally, there is one student (5\%) who has fair score. It shows that she/he fails in pronouncing English consonant sounds accurately. 


\section{The Result of Questionnaire}

As mentioned in the previous section, the questionnaire is distributed to students to get their opinion, point of view, and their personal feeling about the use of WhatsApp group in reducing their pronunciation anxiety in learning consonant sounds. The result of questionnaire is presented in Table 4 as follows:

Table 4 The Result of Questionnaire

\begin{tabular}{|c|c|c|c|c|c|}
\hline \multirow[t]{3}{*}{ No } & \multirow[t]{3}{*}{ Statement } & \multicolumn{4}{|c|}{$\begin{array}{c}\text { Number of Students and Percentage of } \\
\text { Answer Given }\end{array}$} \\
\hline & & \multicolumn{2}{|c|}{ Yes } & \multicolumn{2}{|c|}{ No } \\
\hline & & $\begin{array}{c}\text { Number of } \\
\text { students }\end{array}$ & $\%$ & $\begin{array}{c}\text { Number } \\
\text { of } \\
\text { students }\end{array}$ & $\%$ \\
\hline 1 & $\begin{array}{l}\text { I feel happy when I learn and practice } \\
\text { English consonant sounds in the } \\
\text { classroom. }\end{array}$ & 9 & $50 \%$ & 9 & $50 \%$ \\
\hline 2 & $\begin{array}{l}\text { I feel relaxed when I learn and practice } \\
\text { English consonant sounds in the } \\
\text { classroom. }\end{array}$ & 10 & $56 \%$ & 8 & $33 \%$ \\
\hline 3 & $\begin{array}{l}\text { I find difficulties when learning and } \\
\text { practicing English consonant sounds in } \\
\text { the classroom. }\end{array}$ & 9 & $50 \%$ & 9 & $50 \%$ \\
\hline 4 & $\begin{array}{l}\text { I feel anxious when learning and } \\
\text { practicing English consonant sounds }\end{array}$ & 10 & $56 \%$ & 8 & $33 \%$ \\
\hline 5 & $\begin{array}{l}\text { I feel comfortable in learning and } \\
\text { practicing English consonant sounds } \\
\text { using social media application. }\end{array}$ & 14 & $78 \%$ & 4 & $22 \%$ \\
\hline 6 & $\begin{array}{l}\text { WhatApp application is helpful } \\
\text { enough to be utilized in learning and } \\
\text { practicing English consonant sounds. }\end{array}$ & 13 & $72 \%$ & 5 & $28 \%$ \\
\hline 7 & $\begin{array}{l}\text { I feel enjoy discussing, learning, } \\
\text { practicing, and sharing about English } \\
\text { consonant sounds using WhatsApp } \\
\text { group. }\end{array}$ & 16 & $89 \%$ & 2 & $11 \%$ \\
\hline 8 & $\begin{array}{l}\text { My classmates in WhatsApp group } \\
\text { help me much in learning and } \\
\text { practicing English consonant sounds. }\end{array}$ & 14 & $78 \%$ & 4 & $22 \%$ \\
\hline 9 & $\begin{array}{l}\text { I get immediate feedback and } \\
\text { correction from the classmates and the } \\
\text { lecturer to my incorrect pronunciation } \\
\text { in WhatsApp group. }\end{array}$ & 16 & $89 \%$ & 2 & $11 \%$ \\
\hline 10 & $\begin{array}{l}\text { I feel enjoyed, relaxed, and have self- } \\
\text { confidence to share my voice in } \\
\text { practicing to pronounce English } \\
\text { consonant sound in WhatsApp group. }\end{array}$ & 14 & $78 \%$ & 4 & $22 \%$ \\
\hline
\end{tabular}


Based on the result of questionnaire presented in Table 4, most of students have positive personal feeling after using WhatsApp group as a tool to improve their self-confidence in learning and practicing English consonant sounds. In the early of Pronunciation Practice course, $50 \%$ of them in average have feeling anxiety, unhappy, finding difficulties to learn English consonant sounds. There may be possible factors influencing the result of this research.

\section{DISCUSSION}

As a part of English language component, pronunciation is required to learn as important as other language component by EFL learners. Pronunciation strongly involves our speech organs in which it relates to the way of learning and practicing to produce accurate sounds of English. The production of English sounds highly determines the accurateness of every word used in oral communication. Without practicing and learning to pronounce English sounds, it is impossible for EFL learners to speak English understandably. Trying to sound like a native speaker is difficult, frustrating, and even hard to do. However, using clear words for speaking in a way that the most listeners can understand without too much effort or confusion is required to get effective communication. Hence, learning and practicing English pronunciation should be maximally carried out by EFL learners Based on findings of this research, most of English Department students at STKIP PGRI Banjarmasin batch 2018 perform good pronunciation practice of English consonant sounds after having practice during eight meetings. However, there is also half of class showing enough good performance indicating that they still have difficulties in learning pronunciation of the sounds. The conclusion derived from Table 3 indicates that the students' performance in practicing English consonant sounds is not satisfied and maximally yet. The large amount of them also perform good pronunciation practice and there is a student who gets fair score in which there will be many factors that should be improved to enhance their abilities.

In the beginning of the Pronunciation Practice course, most of students in this research state that this is the first time they learn English consonant sounds. Entering university and taking English major become the new experience and starting point for them learning English pronunciation. When they were in Senior High School, pronunciation aspect gets less attention in English teaching. There are many things that English teachers in secondary school need to fit into their limited class time to teach listening, reading, speaking, and writing skills. Pronunciation often gets pushed to the minor of the list. Moedjito (2016:31) emphasizes that the curricula of secondary school in Indonesia has to set up reading as the main scope of English teaching and learning. As a result, pronunciation aspect does not get priority to be taught to students due to the fact that the learning material mostly given to students is limited to English language skills only. Pronunciation is only taught integrated into four English language skills in which the teacher does not allocate sufficient feedback on it. As a consequence, students do not have any prior knowledge about pronunciation learning when they continue their studies entering university.

Having no background knowledge in the pronunciation learning process causes some impacts to students when they study the pronunciation in university. At the first time 
learning about the features of English pronunciation, the students only keep silent without any interactive response on classroom discussion. Moreover, when they are asked to pronounce the words or sentences consisting of English consonant sounds in front of the class, they seem to feel shy, insecure, and hesitant. Besides that, their voices are also unclear to listen by their classmates. They are anxious and passive when demonstrating such practice activity both individual and group. The class is dominated by active students only. Those who are classified as passive students are not confident and tend to be silent listeners and learners. This condition leads to the conclusion that the common way of practicing English sounds is not sufficient enough to reduce their anxious feelings.

There are some common ways of pronunciation activity carried out by the Pronunciation Practice lecturer at the English Department of STKIP PGRI Banjarmasin. Drilling, listening and repeating, demonstration, minimal pairs, practice dialogue, and tongue twister learning that are delivered by the lecturer as pronunciation activities do not run successfully for the whole students. Some of them do not participate actively due to the feeling of hesitant and anxious of making error. It can be seen from the result of questionnaire that there are $56 \%$ of students who feel anxious to demonstrate those activities. Lucarz (2014:38) clarifies pronunciation anxiety as a feeling of apprehension experienced by foreign language learners deriving from difficulty of learning which is indicated by cognitive, phsychological, and behavioral symptoms of being anxious. As a result, students with anxiety will undergo extreme worry about performing completely well, reduce their confidence, and influence their emotional intelligence.

Therefore, pronunciation anxiety tends to make students become introvert in communication activities among their classmates. The reason for not participating in communication activities is fear of negative evaluation, most often by classmates. Another reason is that, the students tend to be staying silent in the classroom is low self-efficacy. Some of students regards that their competence is not good enough so that there is a feeling of shy to show it (Lucarz, 2014:48). Regarding the negative effects of anxiety on students' learning issues, in addition, teachers should be well equipped to recognize what conditions that may take the students anxious and try to produce suitable learning condition (Hashempour and Mehrad, 2014:116).

The use of learning media that can facilitate students to have self-confidence and get meaningful feedback is absolutely needed, instead of training them conventionally in the classroom. Afshari and Ketabi (2017:87) emphasize that innovative pronunciation teachers should attempt to move towards autonomous learning. When the process of teaching and learning pronunciation in the classroom is not effective enough to train students in pronouncing English sounds, teachers can try to stimulate students become autonomous learners. They can be actively involved in their own learning by facilitating them with a stage where they can perform their ability without having feeling unconfident and anxious. It means that if the lecturer instructs the students how to pronounce certain word and sentence consisting of English consonant sounds, students become autonomous to some extent in that they may ask, discuss, and share to each other when not familiar how to pronounce a word in English. Hence, WhatsApp group is one of alternative application 
leading to autonomous pronunciation learning and contribute to the improvement of students in pronunciation practice.

Based on the result of questionnaire presented in Table 4, most of students have positive personal feeling towards the use of WhatsApp group in learning and practicing English consonant sounds. There are $78 \%$ of student stating that WhatsApp group plays role to help them much in learning English consonant sounds. Sharing their voice records in pronouncing English consonant sounds give them advantages in reducing their feeling of worry in making error. It can be seen that $89 \%$ of students get immediate feedback and possible correction from their classmates when they produce inaccurate sounds. WhatsApp group enables learning beyond the classroom in which the high availability of lecturers to the students' question can potentially enhance the learning process more interactive. Furthermore, high interaction among students using WhatsApp group will stimulate passive students to be brave in discussion, enhance their participation, and invite them to share their ideas. Finally, most of students feel enjoy after moving from conventional way of learning pronunciation. WhatsApp group provides place for everybody to share anything related to the material being discussed.

Along with the advantages of WhatsApp group as a place for students sharing ideas each other, there are also some weaknesses faced by students as well as the lecturer in managing learning process. WhatsApp application needs the stable internet connection from the user. Not all the students have sufficient mobile data package to make sure that they can always make online with the discussion process alive. As a result, some of students use unstable wifi internet network provided in the campus and even; some of them are off from the discussion. Besides that, playing other classmates voice records in WhatsApp group one by one consume much time. Either the teacher or the students should manage the time when they should online on conducting discussion for learning each of consonant sounds. According to Gon and Rawekar (2017:24), using WhatsApp group requires students and teacher to allocate much time beyond the classroom to create and monitor the discussion. The clear instruction by the teacher to manage the time when does the WhatsApp group member should be available for online discussion is absolutely required.

\section{CONCLUSION AND SUGGESTION}

This research has found out that the students are able to reduce their anxiety in learning English consonant sounds by utilizing WhatsApp group. As a part of pronunciation aspect, English consonant sounds have particular characteristics on its place and manner of articulation. As EFL learners, most of students have no background knowledge about pronunciation concept. When they enter university and take English major, this become the first time for them learning intensively about pronunciation of English. Feeling of shy, fear of negative evaluation, fear of making error and anxiety that the class will laugh to them are the kinds of psychological symptoms that they face pronunciation anxiety. These kinds of feeling will lead them to the serious problem if there is no way to help them reducing these matters. 
Based on the result of this research, finding out such learning tool that facilitates them to enhance their self-confidence is important to gain the learning outcome on Pronunciation Practice course. As we live around with recent technology, WhatsApp application is familiar as mobile communication tools provided with many possible features to be used in learning pronunciation. WhatsApp group is highly provide chance to students show their abilities without being shy to others. The function of WhatsApp group in this case is sharing each other, getting feedback from others, and discussing the material. The process of interactive discussion will reduce students' anxiety in pronunciation learning since the activities are carried out online under the teacher's supervision.

WhatsApp group as an alternative tool can be considered to be utilized for helping students reduce their difficulties in learning pronunciation. By recording their voices in pronouncing English consonant sounds, the students get feedback from their classmates. If a student makes pronunciation error, the other can correct and give the right model. It is beneficial in encouraging students enhance their confidences and motivate them to be active students. Due to this point, possible suggestion is given to the teacher who plays important role in monitoring the use of WhatsApp group for learning. Monitoring the discussion should be conducted in order to make sure that all the WhatsApp group members follow the rules, such as: using respectful language, responding comment respectively without offending others, etc. Another important point for teacher is creating conducive situations for pronunciation practice in the classroom. Regular practice of pronunciation activity should be carried out continuously for gaining the successful learning outcome. Encouraging students' participation is one of the ways to stimulate them to be active in pronunciation practice. Besides that, it will increase attitude towards language learning. Finally, they will have self-confidence and be safe from pronunciation anxiety symptoms.

\section{REFERENCES}

Afshari, S., and Ketabi, S. (2017). Current trends and future directions in teaching English pronunciation. International Journal of Research Studies in Language Learning, 6(2):83-91.

Ahad, A.D., and Lim, S.M.A. (2014). Convenience or nuisance?: the "WhatsApp' dilemma. Procedia:Social and Behavioral Sciences, 155 (189-196).

Gilakjani, A.P., and Ahmadi, M.R. (2011). Why is pronunciation so difficult to learn?. English Language Teaching, 4(3): 74-83.

Gilakjani, A.P., and Sabouri, N.B. (2016). How can EFL teachers help EFL learners improve their English pronunciation?. Journal of Language Teaching and Research, 7(5):967-972.

Gon, S., and Rawekar, A. (2017). Effectivity of E-learning through Whatsapp as a teaching learning tool. MVP Journal of Medical Sciences, 4(1):19-25.

Hamad, M.M. (2017). Using WhatsApp to enhance students' learning of English language "Experience to Share". Higher Education Studies, 7(4):74-87.

Hashempour, S., and Mehrad, A. (2014). The effect of anxiety and emotional intelligence on students' learning process. Journal of Education and Social Policy, 1(2):115122. 
Kelly, G. (2000). How to teach pronunciation. Essex: Pearson Education Limited.

Lokakarya Kurikulum Mengacu Kerangka Kualifikasi Nasional Indonesia. (2017). Banjarmasin: STKIP PGRI Banjarmasin

Lucarz, M.B. (2014). Pronunciation anxiety and willingness to communicate in the foreign language classroom. Proceedings of the International Symposium on the Acquisition of Second Language Speech, Department of Education, Concordia University, (5):36-49.

Moedjito, (2016). The teaching of English pronunciation: perceptions of Indonesian school teachers and university students. English Language Teaching, 9(6):30-41.

Ta'amneh, M.A.A.A. (2017). The effect of using WhatsApp messenger in learning English language among university students. International Research in Education, 5(1):143-151.

Tuncel, H. (2015). The relationship between self-confidence and learning Turkish as a foreign language. Educational Research and Reviews, 10(18):2575-2589. 